\title{
ОЦІНЮВАННЯ ЯКОСТІ ВАРЕНИХ КОВБАСНИХ ВИРОБІВ
}

\author{
Е.В. КАЛАШНИК, А.П. КАЙНАШ, Л.В. СКОРИК \\ Полтавская государственная аграрная академия \\ ОЦЕНКА КАЧЕСТВА ВАРЕНЫХ КОЛБАСНЫХ ИЗДЕЛИЙ
}

\author{
O. KALASHNYK, A. KAINASH, L. SKORYK \\ Poltava State Agrarian Academy \\ QUALITY ASSESSMENT OF COOKED SAUSAGE PRODUCTS
}

\section{https://doi.org/10.36910/6775-2310-5283-2020-13-02}

Мета. Проведення комплексних досліджень показників якості та оцінювання рівня якості ковбаси вареної вищого сорту «Лікарська», щэо виготовлена ТОВ «Глобинський м'ясокомбінат».

Методики. Для оцінювання та встановлення рівня якості ковбаси вареної «Лікарська» виробництва ТОВ «Глобинський м'ясокомбінат» використовували передбачені чинними національними стандартами методи, а саме органолептичні (зовнішній вигляд, колір, смак, запах (аромат), консистенція), фізико-хімічні та мікробіологічні.

Результати. Аналітичними дослідженнями встановлено, щуо зміст реквізитів марковання ковбаси вареної «Лікарська» не відповідає вимогам нормативної документації та нормативно-правових актів. Окрім того, зазначений на маркованні склад ковбаси вареної "Лікарська» не відповідає вимогам стандарту до вищого сорту. 3'ясовано, щчо органолептичні показники якості ковбаси вареної «Лікарська» виробництва ТОВ «Глобинський м'ясокомбінат» такі як: зовнішній вигляд (пошкоджень оболонки немає, напливів фаршу, злипів, бульйонних та жирових набряків виявлено не було), консистенція (пружна), вигляд фаршу на розрізі (ковбаса з однорідною структурою - рожевий фари рівномірно перемішаний без порожнин і сірих плям), запах та смак (відповідають даному виду продукту, вміст прянощів та солі в нормі, сторонній запах та присмак відсутні), форма (ковбаса у вигляді прямого батона, довжина 21 см, без перев'язок) відповідають вимогам нормативної документації. Встановлено високий рівень якості ковбаси вареної «Лікарська», який визначили за отриманою сумою балової очінки.

Експериментальні товарознавчі дослідження були проведені за фізико-хімічними та мікробіологічними показниками, щуо дало змогу встановити: масова частка вологи складає 56,4 \%, крохмаль у зразку не виявлено, масова частка кухонної солі становила 2,4\%. Всі досліджені фізико-хімічні показники не перевищували нормативні значення, які встановлені національним стандартом 
Дослідження мікробіологічних показників якості ковбаси вареної «Лікарська» виробництва ТОВ «Глобинський м'ясокомбінат» дало змогу встановити, щуо за вони відповідають нормативним значенням державного стандарту.

Практична значимість. Результати комплексних товарознавчих досліджень дадуть змогу ТОВ «Глобинський м'ясокомбінат» підвищити рівень якості власної продукиії, удосконалити марковання відповідно до вимог чинної нормативної документації.

Ключові слова: ковбаса, оцінювання, якість, марковання, органолептичні, фізикохімічні, мікробіологічні показники.

Постановка проблеми у загальному вигляді та іï зв'язок із важливими науковими чи практичними завданнями. Наразі актуальною проблемою, що впливає на здоров’я населення, його активність, рівень життя, демографічні аспекти, рівень захворюваності, а в подальшому й на економіку України, є якість та безпечність продуктів харчування. 3 метою забезпечення високого рівня життя людини в державі, розвитку економіки, необхідно приділяти цій проблемі більше уваги. Окрім того, споживачі все менше довіряють якості продуктів харчування, що пропонують на ринку виробники. Це пов'язано з забрудненням навколишнього середовища, а в результаті й сировини, а також із низьким рівнем контролю якості в процесі виробництва продуктів харчування.Відомо, що серед м'ясних товарів ковбасні вироби користуються найбільшою популярністю завдяки різноманітному асортименту, високій харчовій цінності, готовності продукту до вживання, можливості використання для приготування інших страв тощо. Споживання ковбас задовольняє постійну фізіологічну потребу людини в харчових речовинах для підтримання нормальної їі життєдіяльності.

В Україні, як і у всьому світі, загострилася проблема забезпечення якості та безпечності продуктів харчування, недопущення в обіг продукції, що не відповідає вимогам прийнятих нормативних документів та є небезпечною.

Відповідно до чинного національного стандарту, варені ковбаси виробляють із великого переліку сировини, які після наповнення в оболонки піддають обсмажуванню або без нього, з подальшим варінням [1]. Широкий асортимент ковбасних виробів вітчизняного виробництва, що надходить на внутрішній ринок України, не завжди відповідає діючим нормативним вимогам та очікуванням споживачів. Тому, питання оцінювання якості та відповідності вимогам стандартів такого популярного харчового продукту як варені ковбаси, є актуальним. 
Аналіз останніх досліджень, у яких започатковано вирішення проблеми. Питаннями визначення рівня якості варених ковбасних виробів, його покращення займалися провідні науковці в різних країнах. Так, у роботі Якубчак O.M., Тютюн А.I., Кос'янчук H.I. [2] у результаті проведення досліджень було 3'ясовано, що дегустаційна оцінка ковбасних виробів, які реалізуються в умовах агропродовольчих ринків м. Одеси, коливалася від 7,8 до 8,9 балів за дев'ятибаловою шкалою.

Для дослідження якості варених ковбас автором [3] було проведено органолептичну, дегустаційну оцінку їх якості, а також визначені фізикохімічні показники. Підтвердження важливості таких досліджень знаходимо у роботі Ткачової Н.В. [4], у якій проведено оцінку якості варених ковбас вищого сорту «Лікарська» різних торгових марок та встановлено ii відповідність вимогам нормативних документів.

Окрім того, на наш погляд, цікавим напрямом оцінювання рівня якості варених ковбас $\epsilon$ ï порівняльне тестування. Тому, Гулясвим В. М. та Корнієнко I. М. [5] проведено порівняльну характеристику ковбаси вареної вищого сорту «Лікарська» та ковбаси домашньої курячої за фізико-хімічними властивостями [5].

Так як ковбаси відносять до продукції, що підлягає ветеринарносанітарній оцінці, то в роботі Богатко Н. М. та Букалової Н. В. [6], висвітлено даний аспект для ковбасних виробів в ПП «БАЛАЯН М.С.».

В рамках дослідження Franjčec I., Njari B., Cvrtila Fleck Ž. [7] було оцінено якість крендерів як представника варених ковбас на ринку Крапіни Загірський повіт. У хімічних дослідженнях було визначено вміст води, жирів, загального білка, гідроксипроліну та золи. Аналізуючи рівень якості вареної ковбаси, було визначено, що склад усіх досліджених зразків відповідає вимогам нормативних документів Республіки Хорватія.

Аналіз наукових джерел показав, що у напрямку оцінювання рівня якості варених ковбас проведена незначна кількість досліджень. Це підтверджує актуальність проведених товарознавчих досліджень, які наведені у статті.

Таким чином, розширення самостійності м'ясопереробних підприємств, поява нових джерел надходження на споживчий ринок м'ясної продукції різної за якістю, в тому числі фальсифікованої, вимагає всебічного комплексного контролю іiі якості, відповідності чинній нормативній документації (НД).

Цілі статті. Проведення комплексного дослідження показників якості та 
встановлення рівня якості ковбаси вареної вищого сорту «Лікарська» традиційного асортименту, що виготовлена ТОВ «Глобинський м'ясокомбінат».

Для досягнення поставленої мети потрібно було виконати такі завдання:

- дослідити органолептичні, фізико-хімічні та мікробіологічні показники якості ковбаси вареної вищого сорту «Лікарська»;

- на основі проведених досліджень встановити рівень якості даного ковбасного виробу.

Об'єктом дослідження є ковбаса варена вищого сорту «Лікарська», що виготовлена ТОВ «Глобинський м'ясокомбінат».

Методи дослідження. Дослідження, для встановлення рівня якості ковбаси вареної «Лікарська» виробництва ТОВ «Глобинський м'ясокомбінат», проводили за такими методами:

- органолептичне оцінювання за показниками - зовнішній вигляд, колір, консистенція, вигляд фаршу на розрізі, смак, запах (аромат), форма, розмір за допомогою органів чуття відповідно до ДСТУ 4823.2:2007 [8];

- вміст вологи за ДСТУ ISO 1442:2005 [9];

- вміст крохмалю відповідно до ДСТУ ISO 5554:2005. Продукти м ясні. Метод визначення вмісту крохмалю (контрольний метод) [10];

- вміст хлоридів відповідно до ДСТУ ISO 1841-2:2004 [11];

- мікробіологічні показники відповідно до ДСТУ ISO 13681:2007 [12].

Виклад основного матеріалу дослідження з повним обгрунтуванням отриманих результатів. Для встановлення рівня якості ковбаси вареної вищого сорту «Лікарська» виробництва ТОВ «Глобинський м'ясокомбінат» на початку дослідження були проаналізовані відповідність ії марковання та пакування вимогам НД.Слід відмітити, що 6 серпня 2019 року набув чинності Закон України «Про інформацію для споживачів харчових продуктів» [13], який встановлює загальні принципи та вимоги щодо інформації про харчові продукти, зокрема, стосовно їх марковання, а також обов'язки операторів ринку щодо доведення цих даних до споживачів. Він встановлює перелік реквізитів, які є обов'язковими для фасованих харчових продуктів.

Зразок ковбаси вареної був упакований у пакет із плівкового матеріалу, запаяний з обох сторін, цілим батоном, на який нанесена паперова клейка етикетка 3 реквізитами марковання. Аналіз реквізитів марковання ковбаси вареної «Лікарська» виробництва ТОВ «Глобинський м'ясокомбінат», що нанесені на етикетку представлений в таблиці 1. 


\section{Таблиця 1}

Аналіз реквізитів марковання ковбаси вареної «Лікарська» виробництва ТОВ «Глобинський м'ясокомбінат»

\begin{tabular}{|c|c|c|}
\hline $\begin{array}{l}\text { Назва реквізиту } \\
\text { марковання }\end{array}$ & Позначення на маркованні & $\begin{array}{c}\text { Відповідність } \\
\text { ДСТУ } \\
\text { 4436:2005 }\end{array}$ \\
\hline $\begin{array}{l}\text { Назва та повна адреса } \\
\text { підприємства- } \\
\text { виробника, його } \\
\text { товарного знака (за } \\
\text { наявності) та телефон, } \\
\text { адреса об'єкта } \\
\text { виробництва }\end{array}$ & $\begin{array}{l}\text { ТОВбचно } \\
\text { ТОВ «лобинський } \\
\text { м'ясокомбінат»: вул.К.Маркса, 228, м. } \\
\text { Глобине, Полтавська обл., Україна, 39000, } \\
\text { тел. (5365) 2-52-50, 2-51-96 }\end{array}$ & Відповідає \\
\hline Назва & Ковбаса варена «Лікарська» & Відповідає \\
\hline Сорт & Вищий & Відповідає \\
\hline $\begin{array}{l}\text { Склад ковбасних } \\
\text { виробів у порядку } \\
\text { переваги складників } \\
\text { зокрема харчових } \\
\text { добавок, які } \\
\text { використовували під час } \\
\text { їх виробництва }\end{array}$ & 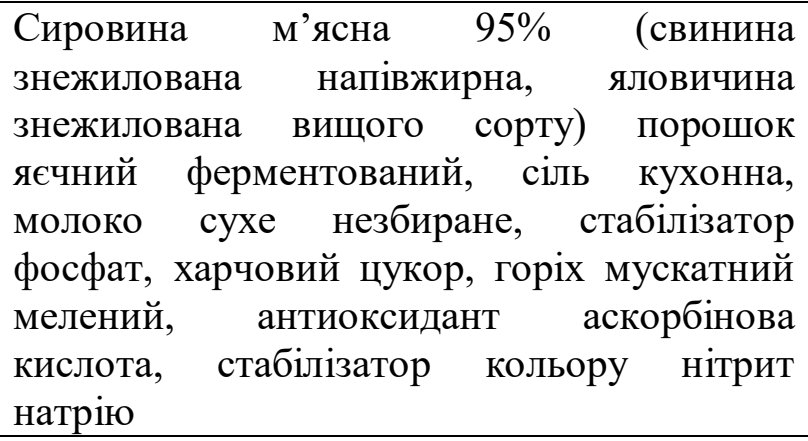 & Відповідає \\
\hline $\begin{array}{l}\text { Кінцева дата } \\
\text { споживання «Вжити } \\
\text { до...» або дата } \\
\text { виготовляння та строку } \\
\text { придатності } \\
\end{array}$ & $\begin{array}{l}\text { Дата виробництва - 10.09.19; } \\
\text { вжити до - 24.09.2019 }\end{array}$ & Відповідає \\
\hline $\begin{array}{l}\text { Строк зберігання без } \\
\text { пакування }\end{array}$ & 3 доби & \\
\hline Умови зберігання & Відсутні & $\begin{array}{c}\text { Не } \\
\text { відповідає }\end{array}$ \\
\hline Маса нетто & 0,515 кг & Відповідає \\
\hline $\begin{array}{l}\text { Поживна харчова } \\
\text { цінність } 100 \text { г продукту }\end{array}$ & Білок 13,0 г; жир 22,0 г; вуглеводи 1,0 г & Відповідає \\
\hline $\begin{array}{l}\text { Енергетична цінність } \\
\text { (калорійність) } 100 \text { г } \\
\text { продукту }\end{array}$ & 1046,0 кДж (250,0 ккал) & Відповідає \\
\hline Позначення стандарту & ДСТУ 4436:2005 & Відповідає \\
\hline $\begin{array}{l}\text { Штрих-код EAN - згідно } \\
3 \text { ДСТУ } 3147\end{array}$ & 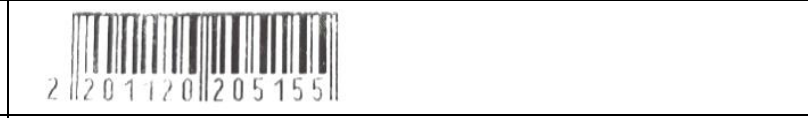 & Відповідає \\
\hline $\begin{array}{l}\text { Tемпература } \\
\text { зберігання, }{ }^{\circ} \mathrm{C} \\
\text { Відносна вологість } \\
\end{array}$ & $\begin{array}{l}0-6 \\
75 \%\end{array}$ & \\
\hline Наявність ГМО & 5 & \\
\hline
\end{tabular}


Аналіз реквізитів, що зазначені на пакованні ковбаси вареної «Лікарська» показав відсутність такого реквізиту як умови зберігання або умови використання харчового продукту. Наявність цього реквізиту регламентує i ст.20 Закону України «Про інформацію для споживачів харчових продуктів» [13]. Таким чином, марковання ковбаси вареної «Лікарська» не відповідає вимогам ДСТУ 4436:2005 [1] та Закону України «Про інформацію для споживачів харчових продуктів» [13].

Окрім того, на оболонці ковбаси вареної «Лікарська» також позначені реквізити марковання, аналіз яких поданий у таблиці 2.

Таблиця 2

\section{Аналіз реквізитів марковання ковбаси вареної «Лікарська» виробництва} ТОВ «Глобинський м'ясокомбінат», що зазначені на оболонці

\begin{tabular}{|c|c|c|}
\hline Назва реквізиту маркування & $\begin{array}{c}\text { Реквізит марковання, що } \\
\text { зазначений на виробі }\end{array}$ & $\begin{array}{c}\text { Відповідність } \\
\text { ДСТУ 4436:2005 } \\
{[1]}\end{array}$ \\
\hline $\begin{array}{l}\text { Назва та повна адреса підприємства- } \\
\text { виробника, його товарний знак (за } \\
\text { наявності) та телефон, адреса об’єкта } \\
\text { виробництва }\end{array}$ & एवक्तम & $\begin{array}{l}\text { Відповідає } \\
\text { частково }\end{array}$ \\
\hline $\begin{array}{l}\text { Назва, сорт та склад ковбасних виробів } \\
\text { у порядку переваги складників, } \\
\text { зокрема харчових добавок, які } \\
\text { використовували під час їх } \\
\text { виробництва }\end{array}$ & $\begin{array}{c}\text { Ковбаса варена } \\
\text { «Лікарська» }\end{array}$ & $\begin{array}{l}\text { Відповідає } \\
\text { частково }\end{array}$ \\
\hline $\begin{array}{l}\text { Кінцева дата споживання «Вжити до...» } \\
\text { або дата виготовляння та строк } \\
\text { придатності }\end{array}$ & Відсутній & Не відповідає \\
\hline Умови зберігання & Відсутній & Не відповідає \\
\hline $\begin{array}{l}\text { Інформаційні дані про харчову та } \\
\text { енергетичну цінність } 100 \text { г продукту }\end{array}$ & Відсутній & Не відповідає \\
\hline Позначення стандарту & - & Не відповідає \\
\hline
\end{tabular}

Отже, у результаті проведених аналітичних досліджень можна стверджувати, що на оболонці ковбаси вареної «Лікарська» виробництва ТОВ «Глобинський м'ясокомбінат» зазначений не повний перелік реквізитів марковання. Таким чином, марковання оболонки ковбаси вареної не відповідає вимогам нормативної документації [1].

Відповідно до п. 5.2.8 ДСТУ 4436:2005 [1] ковбаси варені, залежно від сорту, виготовляють із дотриманням обмежень щодо сировини. Для ковбаси вареної «Лікарська» вищого сорту така сировина як: м'ясо знежиловане, сало, жир-сирець, субпродукти, сир, вершки, яйця курячі, олія повинна становити 
не менше ніж 100 \%. Зазначений на маркованні склад ковбаси вареної «Лікарська» (таблиця 1) не відповідає вимогам стандарту до вищого сорту.

Розмір батону вимірювали за допомогою лінійки. Цей показник складає 21 см, що є допустимим за НД. Потім визначали масу ковбаси вареної «Лікарська» виробництва ТОВ «Глобинський м'ясокомбінат» на вагах для статичного зважування звичайного класу точності 3 допустимою похибкою \pm 1 г. Маса ковбаси вареної «Лікарська» складає 515 г, що відповідає реквізиту марковання, зазначеному виробником на паперовій етикетці.

Наступним етапом проведення дослідження було визначення органолептичних показників згідно ДСТУ 4823.2:2007 [8]. Органолептичну оцінку проводили для встановлення відповідності органолептичних показників якості ковбаси вареної «Лікарська» виробництва ТОВ «Глобинський м'ясокомбінат» за допомогою органів відчуття 3 визначенням таких показників як: зовнішній вигляд, консистенція, вигляд фаршу на розрізі, запах та смак, форма [1]. Аналіз результатів дослідження органолептичних показників якості ковбаси вареної «Лікарська» виробництва ТОВ «Глобинський м'ясокомбінат» представлений у таблиці 3.

Таблиця 3

\section{Органолептичні показники якості ковбаси вареної «Лікарська»}

\begin{tabular}{|c|c|c|c|}
\hline \multirow{2}{*}{$\begin{array}{c}\text { Назва } \\
\text { показника }\end{array}$} & \multicolumn{2}{|c|}{ Характеристика } & \multirow{2}{*}{$\begin{array}{c}\text { Відповідність } \\
\text { вимогам НД }\end{array}$} \\
\hline & за ДСТУ 4436:2005 [1] & зразка & \\
\hline $\begin{array}{c}\text { Зовнішній } \\
\text { вигляд }\end{array}$ & $\begin{array}{c}\text { Батони варених ковбас } 3 \\
\text { чистою сухою поверхнею без } \\
\text { пошкодження оболонки, } \\
\text { напливів фаршу, злипів, } \\
\text { бульйонних та жирових } \\
\text { набряків. }\end{array}$ & $\begin{array}{c}\text { Пошкоджень оболонки } \\
\text { немає, напливів } \\
\text { фаршу, злипів, } \\
\text { бульйонних та } \\
\text { жирових набряків } \\
\text { виявлено не було }\end{array}$ & Відповідає \\
\hline Консистенція & Пружна & Пружна & Відповідає \\
\hline $\begin{array}{c}\text { Вигляд } \\
\text { фаршу на } \\
\text { розрізі }\end{array}$ & $\begin{array}{c}\text { Рожевий або світло-рожевий } \\
\text { фарш рівномірно } \\
\text { перемішаний без порожнин і } \\
\text { сірих плям }\end{array}$ & $\begin{array}{c}\text { Ковбаса з однорідною } \\
\text { структурою - рожевий } \\
\text { фарш рівномірно } \\
\text { перемішаний без } \\
\text { порожнин і сірих плям }\end{array}$ & Відповідає \\
\hline Запах та смак & $\begin{array}{c}\text { Властиві даному виду } \\
\text { продукту, з ароматом } \\
\text { прянощів, в міру солоний, } \\
\text { без стороннього запаху та } \\
\text { присмаку } \\
\end{array}$ & $\begin{array}{c}\text { Відповідають даному } \\
\text { виду продукту, вміст } \\
\text { прянощів та солі в } \\
\text { нормі, сторонній запах } \\
\text { та присмак відсутні } \\
\end{array}$ & Відповідає \\
\hline $\begin{array}{l}\text { Форма, розмір } \\
\text { та товарна } \\
\text { відмітка } \\
\text { батонів } \\
\end{array}$ & $\begin{array}{c}\text { Прямі батони довжиною до } \\
60 \text { см } 3 \text { двома поперечними } \\
\text { перев’язками на верхньому } \\
\text { кінці батона. } \\
\end{array}$ & $\begin{array}{c}\text { Ковбаса варена у } \\
\text { вигляді прямого } \\
\text { батона, довжина } \\
21 \text { см, без перев'язок }\end{array}$ & Відповідає \\
\hline
\end{tabular}


Проведеними дослідженнями встановлено, що органолептичні показники якості ковбаси вареної «Лікарська» відповідають вимогам НД [1]. Для визначення рівня якості ковбаси вареної «Лікарська» була проведена балова оцінка якості за 5-ти баловою шкалою 3 оцінюванням наступних показників: зовнішній вигляд, консистенція, вигляд фаршу на розрізі, запах, смак, соковитість, форма, розмір та товарна відмітка батонів. Результати балової оцінки якості ковбаси вареної «Лікарська» виробництва ТОВ «Глобинський м'ясокомбінат» наведені на пелюстковій діаграмі 1.

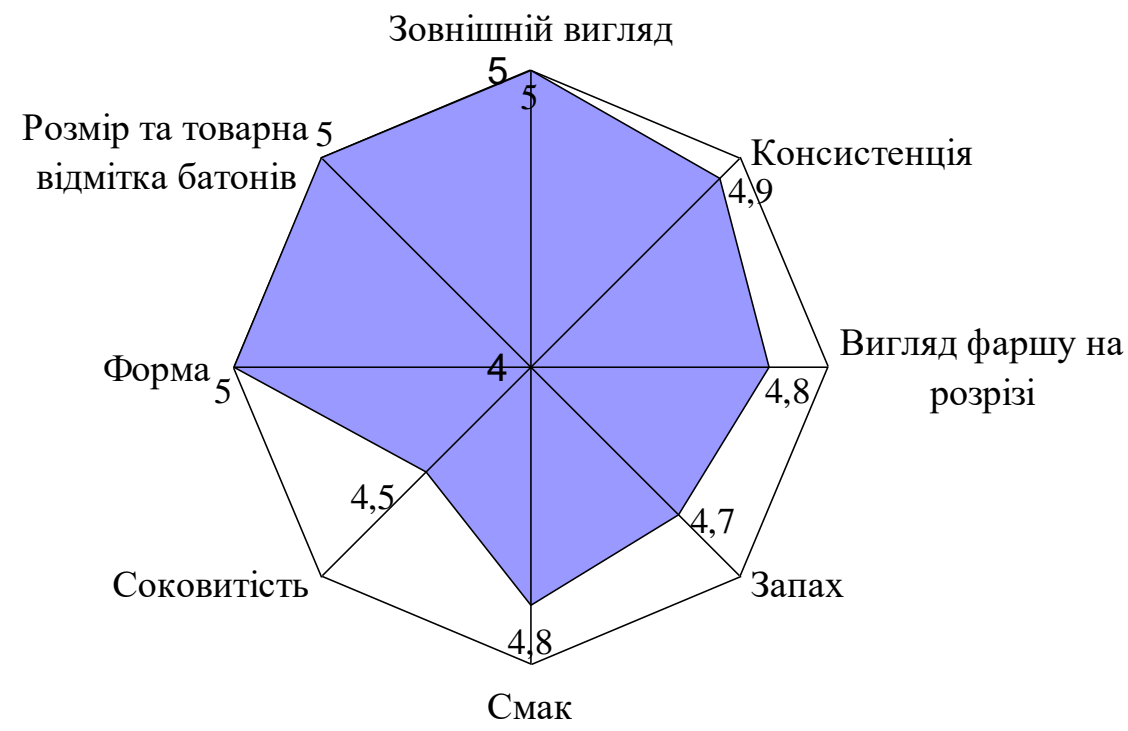

\section{Рис. 1. Результати балової оцінки якості ковбаси вареної «Лікарська» виробництва ТОВ «Глобинський м'ясокомбінат»}

На основі результатів проведеної балової оцінки та розроблених рівнів якості встановлено, що середній бал становить 4,8, що відповідає високому рівню якості.

Під час визначення фізико-хімічних показників якості ковбаси вареної «Лікарська» виробництва ТОВ «Глобинський м'ясокомбінат» були отримані такі результати, що представлені у таблиці 4.

Таблиця 4

Результати дослідження фізико-хімічних показників якості ковбаси вареної «Лікарська» виробництва ТОВ «Глобинський м'ясокомбінат»

\begin{tabular}{|l|c|c|c|}
\hline \multirow{2}{*}{\multicolumn{1}{|c|}{ Назва показника }} & \multicolumn{2}{|c|}{ Значення показника } & \multirow{2}{*}{ Відповідність } \\
\cline { 1 - 3 } & за ДСТУ 4436:2005 [1] & зразка & НД \\
\hline Масова частка вологи, \% & Не більше ніж 65,0 & 56,4 & Відповідає \\
\hline Масова частка крохмалю & Не допускається & Не виявлено & Відповідає \\
\hline Масова частка кухонної солі, \% & Не більше ніж 2,5 & 2,4 & Відповідає \\
\hline
\end{tabular}


Проведений аналіз фізико-хімічних показників якості ковбаси вареної «Лікарська» виробництва ТОВ «Глобинський м'ясокомбінат» свідчить про те, що дана продукція відповідає вимогам ДСТУ 4436:2005 [1].

Під час проведення мікробіологічних досліджень використовували два види поживних середовища МПА (м'ясо-пептонний агар) та СА (сусло агар) [12].

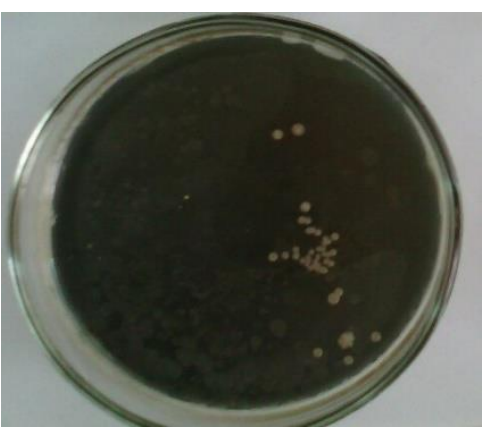

Рис. 2. Ріст колоній бактерій на МПА

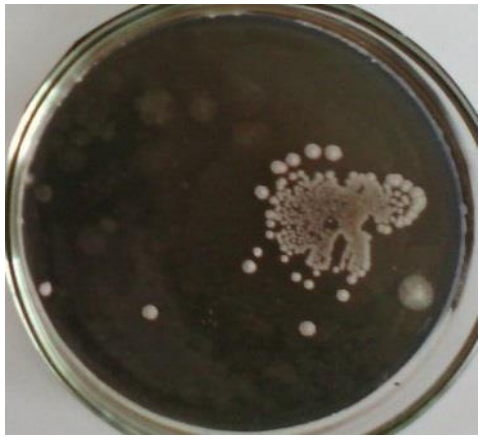

Рис. 4. Ріст колоній грибів на С/А
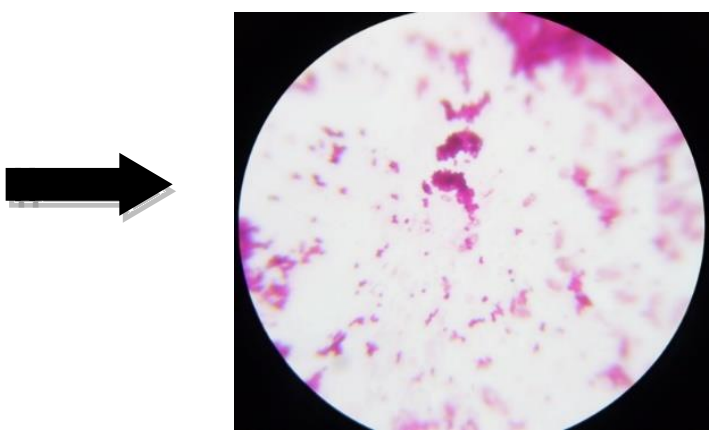

Рис. 3. Бактерії колонії 2-го типу, грамнегативні диплококи 0,3-0,5 мкм

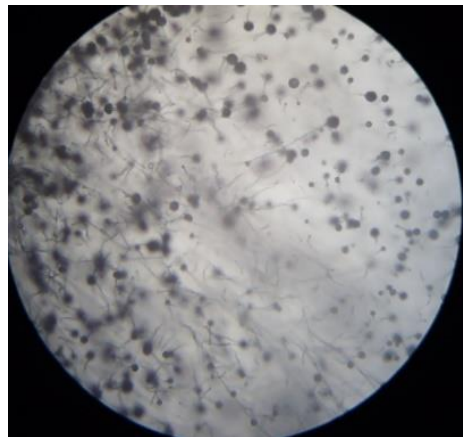

Рис. 5. Ріст грибів під мікроскопом

За результатами визначення мікробіологічних показників якості ковбаси вареної «Лікарська» виробництва ТОВ «Глобинський м'ясокомбінат» (рис. 25) було встановлено, що за показниками МАФАнМ ковбаса варена «Лікарська» виробництва ТОВ «Глобинський м'ясокомбінат» відповідає санітарним нормам СанПиН 2.3.2.560-96 «Гигиенические требования к качеству и безопасности продовольственного сырья и пищевых продуктов» [14].

Під час дослідження колоній мікроорганізмів, що виросли на МПА, були виявлені грамнегативні мікрококи розміром 0,1-0,2 мкм та диплококи розміром від 0,3 до 0,5 мкм. При дослідженні колоній, що виросли на C/A у зразку були виявлені гриби роду пеніциліум (Penicillium), наявність яких не перевищує санітарні норми. Дріжджів у ковбасі вареній «Лікарська» не було виявлено. 
Висновки та перспективи подальших досліджень. Проведені дослідження органолептичних, фізико-хімічних та мікробіологічних показників якості ковбаси вареної вищого сорту «Лікарська» традиційного асортименту, що виготовлена ТОВ «Глобинський м’ясокомбінат» показали, що $\epsilon$ деякі відхилення окремих показників від вимог нормативної документації. Аналіз реквізитів марковання ковбаси вареної «Лікарська» засвідчив, що їх зміст не відповідає вимогам нормативної документації. Окрім того, зазначений на маркованні склад ковбаси вареної «Лікарська» не відповідає вимогам стандарту до вищого сорту.

Під час проведення досліджень встановлено, що органолептичні показники якості ковбаси вареної «Лікарська» виробництва ТОВ «Глобинський м'ясокомбінат» такі як: зовнішній вигляд, консистенція, вигляд фаршу на розрізі, запах та смак, форма відповідають вимогам нормативної документації. Встановлено високий рівень якості ковбаси вареної «Лікарська», який визначили за отриманою сумою балової оцінки.

На основі проведених досліджень якості ковбаси вареної «Лікарська» виробництва ТОВ «Глобинський м'ясокомбінат» за фізико-хімічними показниками встановлено, що: масова частка вологи відповідає нормативним значенням та складає 56,4 \%, масова частка крохмалю не допускається і у зразку його виявлено не було, та масова частка кухонної солі становила 2,4 \%, що не перевищує нормативне значення, регламентоване ДСТУ 4436:2005.

Дослідження мікробіологічних показників якості ковбаси вареної «Лікарська» виробництва ТОВ «Глобинський м'ясокомбінат» дало змогу встановити, що за показниками МАФАнМ ковбаса варена «Лікарська» виробництва ТОВ «Глобинський м'ясокомбінат» відповідає санітарним нормам. Також були виявлені грамнегативні мікрококи розміром 0,1-0,2 мкм та диплококи розміром від 0,3 до 0,5 мкм; гриби роду пеніциліум (Penicillium), наявність яких не перевищує санітарні норми. Дріжджів у ковбасі вареній «Лікарська» не було виявлено.

Перспективи подальших досліджень. ТОВ «Глобинський м'ясокомбінат» потрібно привести марковання ковбаси вареної «Лікарська» у відповідність до вимог законодавства України та нормативних документів. Після дослідження органолептичних, фізико-хімічних та мікробіологічних показників якості ковбаси вареної вищого сорту «Лікарська» традиційного асортименту, що виготовлена ТОВ «Глобинський м'ясокомбінат» планується проведення досліджень показників безпечності відповідно до п. 5.1.5 ДСТУ 4436:2005. 


\section{Список використаних джерел}

1. ДСТУ 4436:2005. Ковбаси варені, сосиски, сардельки, хліби м'ясні. Загальні технічні умови. [Чинний від 2007-01-01]. Київ, 2006. 32 с. (Інформація та документація).

2. Органолептична і дегустаційна оцінка ковбасних виробів / Ушаков Ф. О., Якубчак О. М., Тютюн А. І., Кос'янчук Н. I. // Наукові доповіді Національного університету біоресурсів і природокористування України. 2016. № 4. Режим доступу: http://nbuv.gov.ua/UJRN/Nd_2016_4_24 . (дата звернення: 03.09.2019).

3. Бургу Ю. Г. Товарознавча характеристика варених ковбас. Науковий вісник Полтавського університету економіки і торгівлі. № 1 (46). 2010. С. 60-63.

4. Ткачова Н. В. Оцінка якості варених ковбасних виробів [Електронний ресурс] // Наукові доповіді НУБіП. 2010. URL: http://nd.nubip.edu.ua/2010-6/10tnvbsp.pdf . (дата звернення: 02.09.2019).

5. Дослідження порівняльної характеристики ковбас - вареної вищого сорту «Лікарська» та власноруч виготовленої домашньої курячої за фізико-хімічними властивостями / В. М. Гуляєв, І. М. Корнієнко, О. С. Радченко // Збірник наукових праць Дніпродзержинського державного технічного університету. Технічні науки. - 2015. - Вип. 1. - С. 269-273. - Режим доступу: http://nbuv.gov.ua/UJRN/Znpddtu_2015_1_56 (дата звернення: 05.09.2019).

6. Богатко Н. М., Букалова Н. В., Власенко В. В. Ветеринарно-санітарна оцінка ковбасних виробів в ПП «Балаян М.С.» м. Феодосія за показниками якості та безпеки // Збірник наукових праць ВНАУ Безпека продуктів харчування та технологія переробки. 2011. № 11 (51). C.136-140 URL: http://repository.vsau.org/getfile.php/3395.pdf.

7. Franjčec I., Njari B., Fleck Ž. Evaluation of marketable quality of cooked sausages [Електронний ресурс] // MESO: Prvi hrvatski časopis o mesu. 2011. URL: https://hrcak.srce.hr/index.php?show=clanak\&id_clanak_jezik=120171. (дата звернення: 04.09.2019).

8. ДСТУ 4823.2:2007. Продукти м`ясні. Органолептичне оцінювання показників якості. Частина 2. Загальні вимоги. (ISO 4823.2:1998, IDT). [Чинний від 2009-01-01]. Київ, 2008. 14 с. (Інформація та документація).

9. ДСТУ ISO 1442:2005. М'ясо та м'ясні продукти. Метод визначення вмісту вологи (контрольний метод). (ISO 1442:1997, IDT). [Чинний від 2007-04-01]. Київ, 2007. 8 с. (Інформація та документація).

10. ДСТУ ISO 5554:2005. Продукти м'ясні. Метод визначення вмісту крохмалю (Контрольний метод) (ISO 5554:1998, IDT). [Чинний від 2008-01-03]. Київ, 2008. 12 с. (Інформація та документація).

11. ДСТУ ISO 1841-2:2004. М'ясо та м'ясопродукти. Визначення вмісту хлоридів. Частина 2. Потенціометричний метод (ISO 1841-2:1996, IDT). [Чинний від 2006-01-01]. Київ, 2005. 10 с. (Інформація та документація).

12. ДСТУ ISO 13681:2007. М'ясо та м'ясні продукти. Метод визначення кількості колоній дріжджів і пліснявих грибів (ISO 13681:1995, IDT). [Чинний від 2009-01-01]. Київ, 2008. 12 с. (Інформація та документація). 
13. Про інформацію для споживачів щодо харчових продуктів : Закон України // Відомості Верховної Ради (ВВР), 2019, № 7, ст.41 https://zakon.rada.gov.ua/laws/show/263919. (дата звернення: 04.09.2019).

14. Гигиенические требования к качеству и безопасности продовольственного сырья и пищевых продуктов: СанПиН 2.3.2.560-96. Введ. 2002-09-01. Санитарные нормы и правила, 2002. 40 с. (Інформація та документація).

\section{References}

1. Kovbasy vareni, sosysky, sardelky, khliby m'iasni: DSTU 4436:2005. - [Chynnyi vid 2006-01-07 zi zminamy № 1 vid 2008-20-07]. [Sausages, frankfurters, sausages, meat loaf, ISO 4436: 2005. [Effective as of 2006-01-07 with amendments number 1 on 2008-20-07]]. State Committee for Technical Regulation and Consumer Policy of Ukraine, 98. (National Standard of Ukraine).

2. Yakubchak, O.M., Tiutiun, A.I., \& Kos'ianchuk, N.I. (2016). Orhanoleptychna i dehustatsiina otsinka kovbasnykh vyrobiv. Naukovi dopovidi Natsionalnoho universytetu bioresursiv i pryrodokorystuvannia Ukrainy. 4(61), 1-9. Retrieved from http://journals.uran.ua/index.php/2223-1609/article/view/113223/107743.

3. Burgu, Y.G. (2010). Tovaroznavcha kharakterystyka varenykh kovbas. Naukovij visnik Poltavs `kogo universitetu ekonomiki i torgivli, 1 (46), 60-63.

4. Tkachova, N.V. (2010). Oczinka yakosti varenix kovbasnix virobiv . Naukovi dopovidi Naczional nogo universitetu bioresursiv i prirodokoristuvannya Ukraïni, 1, 1-6. Retrieved from http://nd.nubip.edu.ua/2010-6/10tnvbsp.pdf.

5. Gulya€v, V.M., Korniєnko , I.M., \& Radchenko, O.S. (2015). Doslidzhennia porivnialnoi kharakterystyky kovbas - varenoi vyshchoho sortu «Likarska» ta vlasnoruch vyhotovlenoi domashnoi kuriachoi za fizyko-khimichnymy vlastyvostiamy. Zbirnik naukovix pracz Dniprovs `kogo derzhavnogo texnichnogo universitetu. Texnichni nauki., 269-273. Retrieved from http://nbuv.gov.ua/UJRN/Znpddtu_2015_1_56.

6. Bogatko, N.M., Bukalova, N.V., \& Vlasenko, V.V. (2011). Veterinarno-sanitarna oczinka kovbasnix virobiv v PP «Balayan M.S.» m. Feodosiya za pokaznikami yakosti ta bezpeki. Zbirnik naukovix pracz' VNAU Bezpeka produktiv xarchuvannya ta texnologiya pererobki, 11(51), 136140. Retrieved from http://repository.vsau.org/getfile.php/3395.pdf.

7. Franjčec, I., \& Njari, B. (2011). Evaluation of marketable quality of cooked sausages . MESO: Prvi hrvatski časopis o mesu, Vol. XIII No. 5, 350-353. Retrieved from https://hrcak.srce.hr/index.php?show=toc\&id_broj=6514.

8. DSTU 4823.2:2007. Produkti m`yasni. Organoleptichne oczinyuvannya pokaznikiv yakosti. Chastina 2. Zagal’ni vimogi. (ISO 4823.2:1998, IDT). (01.01.2009) Kiïv: DERZhSPOZhIVSTANDART UKRAÏNI.

9. DSTU ISO 1442:2005. M yaso ta m 'yasni produkti. Metod viznachennya vmistu vologi (kontrol’nij metod). (ISO 1442:1997, IDT). (01.04.2007) Kiïv: Derzhspozhivstandart Ukraïni.

10. DSTU ISO 5554:2005. Produkti m’yasni. Metod viznachennya vmistu kroxmalyu (Kontrol’nij metod) (ISO 5554:1998, IDT).. (03.01.2008) Kiïv: Derzhspozhivstandart Ukraïni.

11. DSTU ISO 1841-2:2004. M yaso ta m'yasoprodukti. Viznachennya vmistu xloridiv. 
Chastina 2. Potencziometrichnij metod (ISO 1841-2:1996, IDT). (01.01.2006). Kiïv: Derzhspozhivstandart Ukraïni.

12. DSTU ISO 13681:2007. M'yaso ta m'yasni produkti. Metod viznachennya kil 'kosti kolonij drizhdzhiv i plisnyavix gribiv (ISO 13681:1995, IDT). (01.01.2009). Kiïv: Derzhspozhivstandart Ukraïni.

13. Zakon Ukrainy Pro informatsiiu dlia spozhyvachiv shchodo kharchovykh produktiv (2019). Retrieved from https://zakon.rada.gov.ua/laws/show/2639-19.

14. Gigiyenicheskiye trebovaniya k kachestvu i bezopasnosti prodovol'stvennogo syr'ya i pishchevykh produktov: SanPiN 2.3.2.560-96. (2002-09-01). Sanitarnyye normy i pravila. Retrieved from http://docs.cntd.ru/document/9052436.

Цель. Проведение комплексных исследований показателей качества и оценки соответствующего уровня качества колбасы вареной высшего сорта «Докторская» традиционного ассортимента, изготовленная ООО «Глобинский мясокомбинат».

Методики. Для оценки и установления уровня качества колбасы вареной «Докторская» производства ООО «Глобинский мясокомбинат» использовали предусмотренные действующими национальными стандартами методы, а именно органолептические (внешний вид, ивет, вкус, запах (аромат), консистенция), физикохимические и микробиологические.

Результаты. Аналитическими исследованиями установлено, что содержание реквизитов маркировки колбасы вареной «Докторская» не соответствует требованиям нормативной документачии и нормативно-правовых актов. Кроме того, указанный на маркировке состав колбасы вареной “Докторская» не соответствует требованиям стандарта к высшему сорту. Установлено, что органолептические показатели качества колбасы вареной «Докторская» производства ООО «Глобинский мясокомбинат» такие как внешний вид (повреждений оболочки нет, напльвов фарша, из липы, бульонных и жировых отеков обнаружено не было), консистенция (упругая), вид фарша на разрезе (колбаса с однородной структурой - розовый фари равномерно перемешан без полостей и серых пятен), запах и вкус (соответствуют данному виду продукта, содержание пряностей и соли в норме, посторонний запах и привкус отсутствуют), форма (колбаса в виде прямого батона, длина 21 см, без перевязок) соответствуют требованиям нормативной документачии. Установлен высокий уровень качества колбасы вареной «Докторская», который определили по полученной сумме балловой очзенки.

Экспериментальные товароведные исследования были проведень по физикохимическим и микробиологическим показателям, что позволило установить: массовая доля влаги составляет 56,4\%, крахмал в образие не обнаружено, массовая доля поваренной соли составляла 2,4\%. Все исследованные физико-химические показатели не превышали нормативные значения, установленные начиональным стандартом.

Исследование микробиологических показателей качества колбасы вареной «Докторская» производства ООО «Глобинский мясокомбинат» позволило установить, что за они соответствуют нормативным значениям стандарта.

Практическая значимость. Результаты комплексных товароведных исследований позволят ООО «Глобинский мясокомбинат» повысить уровень качества своей продукиии, 
усовершенствовать маркировку в соответствии $c$ требованиями действующей нормативной документации.

Ключевые слова: колбаса, оченка, качество, маркировка, органолептические, физико-химические, микробиологические показатели.

The purpose is conducting studies of quality indicators and evaluating the appropriate quality level of «Likarska» prime grade cooked sausage of the traditional assortment, manufactured by LLC «Globine meat packing factory».

Methodology. To assess and establish quality level of «Likarska» cooked sausage produced at LLC «Globine meat-packing factory» the methods envisaged by the current national standards, namely organoleptic (appearance, color, taste, smell (flavor), consistency), also physicalchemical and microbiological methods were used.

Findings. As a result of analytical studies it has been determined that property labeling contents of «Likarska» cooked sausage does not meet the requirements of regulatory documentation and regulatory-legal enactments. In addition, the composition of «Likarska» cooked sausage indicated on the labeling does not meet the requirements of the top grade standard. It has been found out, that organoleptic quality indicators of «Likarska» cooked sausage produced by LLC "Globine meat packing factory» such as: appearance (there were no casing defects, no mince flow, adhesion, broth and fat swelling were revealed), consistency (elastic), mince appearance on the cut (sausage with smooth composition - pink mince, evenly mixed without emptiness and grey spots), smell and taste (met the requirements to the given kind of product, spice and salt content corresponded to the standard, foreign smell and aftertaste were absent), form (sausage had a straight link shape, $21 \mathrm{~cm}$ length, without tying) meet the requirements of the regulatory documentation. High quality level of «Likarska» cooked sausage was established, which was determined by the amount of scores. Experimental commodity research studies have been conducted according to physical-chemical and microbiological indicators which enabled to establish that moisture weight part made $56.4 \%$, without starch in the studied sample, and salt weight part made $2.4 \%$. All the examined physical-chemical indices did not exceed normative values, established by the national standard.

Studying microbiological quality indices of «Likarska» cooked sausage produced by LLC "Globine meat packing factory» has enabled to determine that they meet normative values of the state standard.

The practical value. The results of complex commodity research studies will enable LLC «Globine meat packing factory» to improve the quality of its own products, and also labeling in accordance with the requirements of the current regulatory documentation.

Keywords: sausage, evaluation, quality, labeling, organoleptic, physical-chemical, microbiological indicators.

Стаття рекомендована до друкудоктором сільсько-господарчських наук, професором Полтавської державної аграрної академії Поліщуком А.А.

Стаття надійшла в редакиію 07.12.2019 р. 